\title{
Antibodies to Coxsackie B Viruses and HLA in Japanese with Juvenile-Onset Type 1 (Insulin-Dependent) Diabetes Mellitus
}

\author{
T. Sakurami ${ }^{1}$, N. Nabeya, K. Nagaoka ${ }^{2}$, A. Matsumori ${ }^{3}$, S. Kuno ${ }^{4}$ and A. Honda ${ }^{5}$ \\ ${ }^{1}$ First Division of Internal Medicine, Shimane Medical University, Izumo, ${ }^{2}$ Second and ${ }^{3}$ Third Divisions of Internal Medicine, \\ Faculty of Medicine, Kyoto University, Kyoto, ${ }^{4}$ Department of Internal Medicine, Osaka Red Cross Hospital, Osaka \\ and ${ }^{5}$ Kyoto Red Cross Blood Center, Japan
}

Summary. One hundred and three patients with juvenile-onset Type 1 (insulin-dependent) diabetes mellitus have been studied for evidence of previous Coxsackie $B$ virus infection and compared with age- and sex-matched controls. Coxsackie B4 or B3 neutralization titre $\geqslant 80$ were more common among the patients than among the control subjects, but showed no association with HLA-B phenotypes.

Key words: Coxsackie $B$ viruses, Type 1 diabetes mellitus, HLA, neutralization titres, Japan.

The question of a causal relationship of Coxsackie B viruses to juvenile-onset Type 1 (insulin-dependent) diabetes mellitus remains enigmatic. Coxsackie B4 virus has in one instance been isolated from the pancreas of a patient [1], and a number of other viruses, including those of mumps, rubella and cytomegalovirus, have been implicated, although much of the evidence remains circumstantial [2,3]. Epidemiological observations suggest that Type 1 diabetes may follow Coxsackie virus B4 infections by weeks [4]. A seasonal variation in incidence is well established and lends credence to the theory of a viral provocation [5]. The present study investigates the possible association of Coxsackie $B$ viral antibodies on Type 1 diabetes in Japan, with particular reference to the HLA-B antigens associated with the disease in Japanese patients.

\section{Patients and Methods}

One hundred and three Japanese patients with Type 1 diabetes were studied while attending summer camps for diabetic children in the Kinki region (Kyoto and Osaka areas). Forty-six of the pa- tients were girls aged 3-20 years (average 10.6 years) and 57 were boys aged $8-14$ years (average 11.4 years). The duration of diabetes was less than one year from diagnosis in 19 of 103 patients, 1-3 years in 21 patients and 4 years or over in the remainder. No signs of infectious diseases, such as influenza, were noted during the camps.

Control subjects with no history of active or recent infection were selected from outpatients attending Kyoto University Hospital with various complaints; they were matched as closely as possible for age and sex, and included 46 females and 57 males, aged 3-19 years (average 10.8 years).

A micro-neutralization test was used for the Coxsackie B1-5 antibody studies with a standard volume of 25 ul [6]. HLA-A, -B and -C typing was performed by the standard NIH microcytotoxicity method [7]; data from 101 healthy controls were available for comparison. The $p$ values were corrected for the number of HLAspecificities typed for.

\section{Results}

Table 1 shows the Coxsackie B antibody titres in patients and control subjects. As Coxsackie B group viral antibodies were often found together in low titre in the normal subjects, titres $\geqslant 80$ were defined as 'positive' and the remainder as 'negative'. Differences between the 'positive' and 'negative' groups were compared by Chi-squared test. The results and their significance would remain much the same if the proportions positive at any titre were analysed. The prevalence of raised antibody titres to Coxsackie viruses B4 $\left(\chi^{2}=10.151 ; p<0.002\right)$ and B3 $\left(\chi^{2}=8.503 ; p<\right.$ $0.005)$ were significantly increased compared with the controls, but not for other types of Coxsackie viruses. High titres of Coxsackie B1, B2 and B5 were not encountered in either group, but titres $\geqslant 1280$ to Coxsackie B4 were found only in three patients with diabetes. The distribution of HLA antigens was determined in these patients [8]. HLA-BW54 occurred in 47 
Table 1. Coxsackie B1-5 neutralization titres in Type 1 diabetic patients and control subjects

\begin{tabular}{|c|c|c|c|c|c|c|c|c|c|c|c|}
\hline \multirow[t]{2}{*}{ Coxsackie virus } & & \multicolumn{2}{|l|}{$\mathrm{B} 1$} & \multicolumn{2}{|l|}{ B2 } & \multicolumn{2}{|l|}{ B3 } & \multicolumn{2}{|l|}{ B4 } & \multicolumn{2}{|l|}{ B 5} \\
\hline & & $\begin{array}{l}\text { Diabetic } \\
(n=103)\end{array}$ & $\begin{array}{l}\text { Control } \\
(n=56)\end{array}$ & $\begin{array}{l}\text { Diabetic } \\
(n=103)\end{array}$ & $\begin{array}{l}\text { Control } \\
(n=56)\end{array}$ & $\begin{array}{l}\text { Diabetic } \\
(n=103)\end{array}$ & $\begin{array}{l}\text { Control } \\
(n=56)\end{array}$ & $\begin{array}{l}\text { Diabetic } \\
(n=103)\end{array}$ & $\begin{array}{l}\text { Control } \\
(n=56)\end{array}$ & $\begin{array}{l}\text { Diabetic } \\
(n=103)\end{array}$ & $\begin{array}{l}\text { Control } \\
(n=56)\end{array}$ \\
\hline \multirow{7}{*}{$\begin{array}{l}\text { No. subjects } \\
\text { with } \\
\text { neutralizing } \\
\text { titres of: }\end{array}$} & $\leqslant 20$ & 97 & 50 & 97 & 51 & 65 & 50 & 47 & 45 & 99 & 55 \\
\hline & 40 & 5 & 5 & 3 & 3 & 9 & 2 & 17 & 4 & 4 & 1 \\
\hline & 80 & 0 & 0 & 2 & 1 & 17 & 3 & 15 & 4 & 0 & 0 \\
\hline & 160 & 1 & 1 & 1 & 1 & 6 & 0 & 15 & 2 & 0 & 0 \\
\hline & 320 & 0 & 0 & 0 & 0 & 3 & 1 & 4 & 1 & 0 & 0 \\
\hline & 640 & 0 & 0 & 0 & 0 & 3 & 0 & 2 & 0 & 0 & 0 \\
\hline & $\geqslant 1280$ & 0 & 0 & 0 & 0 & 0 & 0 & 3 & 0 & 0 & 0 \\
\hline \multicolumn{2}{|l|}{$\begin{array}{l}\text { Subjects 'positive' } \\
\quad(\text { titre } \geqslant 80)\end{array}$} & 1 & 1 & 3 & 2 & 29 & 4 & 39 & 7 & 0 & 0 \\
\hline \multicolumn{2}{|l|}{ Number (\%) } & $\underbrace{(1)}$ & (2) & $(\underbrace{3})$ & (4) & $\underbrace{(30)}$ & $(7)$ & $\underbrace{(38)}$ & (13) & $\underbrace{(0)}$ & $(0)$ \\
\hline \multicolumn{2}{|l|}{ Significance $\left(\chi^{2}\right)$} & \multicolumn{2}{|c|}{0.093} & \multicolumn{2}{|c|}{0.062} & \multicolumn{2}{|c|}{8.503} & \multicolumn{2}{|c|}{10.151} & \multicolumn{2}{|c|}{1.096} \\
\hline$p$ & & \multicolumn{2}{|l|}{ NS } & \multicolumn{2}{|l|}{ NS } & \multicolumn{2}{|c|}{$<0.005$} & \multicolumn{2}{|c|}{$<0.002$} & \multicolumn{2}{|l|}{ NS } \\
\hline
\end{tabular}

patients $\left(\chi^{2}=21.20\right.$; corrected $p=0.0002$; relative risk $=5.7)$. We found that there was no association between BW54 and a high titre to either Coxsackie B4 or $\mathrm{B} 3$ viruses.

\section{Discussion}

The significant increase of higher titres of Coxsackie B4 and B3 antibody found here in patients with Type 1 diabetes confirms previous studies [4, 9]. However, there is no reason to believe that the cases with high titres of Coxsackie B4 or B3 have a viral aetiology. There was no significant correlation between the viral antibody titres of the Coxsackie B group and the duration of the diabetes when the patients were divided into two groups, depending on whether the study was performed within one year of the onset of symptoms or later. Reliable diagnosis of pancreatic infection by Coxsackie $B$ viruses is often difficult even during an acute illness.

Type 1 diabetes has several HLA antigen associations, the most common positive associations being with $\mathrm{B} 8, \mathrm{BW} 15, \mathrm{DW} 3 / \mathrm{DR} 3$ and DW4/DR4. There is also a negative association with B7 in Caucasoids [10]. Cudworth and Woodrow [11] considered that all these antigens are in linkage disequilibrium with a specific diabetogenic gene or genes. Also, Cudworth et al. [12] reported that the subjects with Type 1 diabetes who were BW15-positive, and in particular those who were both B8 and BW15 positive, had higher neutralizing antibody titres to Coxsackie virus types B1-B4.
In contrast, Type 1 diabetes in Japan is associated with BW54 [8, 13-15] and not B8, thereby suggesting an ethnic variation of the genes in linkage disequilibrium. We have found that BW54 is not associated with viral antibody titres. We cannot, therefore, immediately generalize Caucasoid results to Japanese patients. It is possible, however, that the aetiological significance of Coxsackie B group viruses in the two populations may lie in their rôle as a trigger for damage to pancreatic $B$ cells.

Acknowledgements. We thank the consultant doctor groups, in particular Dr. K. Izumi, nursing and laboratory staff, and nutritionists of summer camps for diabetic children. Thanks are due to A. Yamamoto for assistance with the manuscript.

\section{References}

1. Yoon JW, Austin M, Onodera T, Notkins AL (1979) Virusinduced diabetes mellitus. N Engl J Med 300: 1173-1179

2. Notkins AL (1977) Virus-induced diabetes mellitus: brief review. Arch Virol 54: 1-17

3. Craighead JE (1975) The role of viruses in the pathogenesis of pancreatic disease and diabetes mellitus. Prog Med Virol 19: $161-184$

4. Gamble DR, Kinsley ML, Fitzgerald MG, Bolton R, Taylor KW (1969) Viral antibodies in diabetes mellitus. Br Med J 3: $627-630$

5. Fleegler FM, Rogers KD, Drash A, Rosenbloom AL, Travis LB, Court JM (1979) Age, sex, and season of onset of juvenile diabetes in different geographic areas. Pediatrics 63:374-379

6. Bell EJ, Grist NR (1970) Further studies of enterovirus infections in cardiac disease and pleurodynia. Scand J Infect 2: 1-6

7. Terasaki PI, Bernoco D, Park MS, Ozturk G, Iwaki Y (1978) Microdroplet testing for HLA-A, -B, $-\mathrm{C}$ and $-\mathrm{D}$ antigen. Am J Clin Pathol 69: 103-120 
8. Sakurami T, Nagaoka K, Nabeya N, Imura H, Kuno S (1980) Islet-cell antibodies and HLA type in Japanese insulin-dependent diabetics. Endocrinol Japon 27: 149-152

9. Gamble DR, Taylor KW, Cumming H (1973) Coxsackie viruses and diabetes mellitus. Br Med J 4: 260-262

10. Irvine WJ, McCallum CJ, Gray RS, Campbell CJ, Duncan LJP, Farquhar JW, Vaughan H, Morris PJ (1977) Pancreatic islet-cell antibodies in diabetes mellitus correlated with the duration and HLA type. Diabetes 26: 138-147

11. Cudworth AG, Woodrow JC (1976) Genetic susceptibility in diabetes mellitus: analysis of the HLA association. Brit Med J 2: $846-848$

12. Cudworth AG, Gamble DR, White GBB, Lendrum R, Woodrow JC, Bloom A (1977) Aetiology of juvenile-onset diabetes -a prospective study. Lancet 1:385-388

13. Wakisaka A, Aizawa M, Matsuura A, Nakagawa S, Nakayama
E, Itakura K, Okuno A, Wagatsuma Y (1976) HLA and juvenile diabetes mellitus in the Japanese. Lancet 2:970-970

14. Kawa A, Nakazawa M, Sakaguchi S, Nakamura S, Kono Y, Kozeki H, Kanehisa T (1977) HLA system in Japanese patients with diabetes mellitus. Diabetes 26:591-595

15. Okimoto K, Juji T, Ishiba $S$, Maruyama $H$, Thoyama $H$, Kosaka K (1978) HLA-BW54 (BW22-J, J-1) antigen in juvenile onset diabetes mellitus in Japan. Tissue Antigens 11: 418-422

Received: 20 May 1981

and in final form: 7 December 1981

Takehiko Sakurami, M. D.

First Division of Internal Medicine

Shimane Medical University

89-1, Enyacho, Izumo-shi 693, Japan 